\title{
KUALITAS MODUL ELEKTRONIK BERBASIS CONTEXTUAL TEACHING AND LEARNING TERINTEGRASI PENDIDIKAN KARAKTER UNTUK MENULIS KARYA ILMIAH
}

The Quality of Electronic Module Based on Integrated Character Building Contextual Teaching and Learning for Scientific Writing

\author{
Winda Noprina dan Dina Fitria Handayani \\ STKIP Adzkia \\ winda@stkipadzkia.ac.id
}

Naskah Diterima Tanggal 21 Januari 2020_Direvisi Akhir Tanggal 17 April 2021—Disetujui Tanggal 9 Juni 2021 doi: https://doi.org/10.26499/rnh.v10i1.3347

\begin{abstract}
Abstrak
Suksesnya pembelajaran di kelas sangat ditentukan oleh perencanaan dosen. Termasuk dalam perencanaan tersebut adalah rencana bahan ajar yang digunakan. Bahan ajar menulis karya ilmiah yang ada selama ini masih merupakan buku-buku ajar atau referensi, belum ada yang menuntun secara spesifik penulisan karya ilmiah dalam bentuk sebuah modul dan juga mengintegrasikan karakter kejujuran yang menjadi salah karakter penting dalam penulisan karya ilmiah. Untuk itu, modul yang disusun harus memiliki kualitas yang baik. Maka, penelitian ini bertujuan menguji kualitas modul elektronik (e-modul) berbasis CTL terintegrasi pendidikan karakter untuk menulis karya ilmiah. Metode penelitian yang digunakan adalah penelitian pengembangan model 4-D pada tahap ke-3 yakni pengembangan (development). EModul diuji tingkat validitas, praktikalitas dan efektivitas. Hasil penelitian menunjukkan bahwa e-modul berbasis CTL yang dirancang tergolong sangat valid dengan persentase validitas $82 \%$. E-modul tergolong praktis baik dari aspek kemudahan dalam penggunaan maupun aspek waktu yang digunakan. Persentase praktikalitas dari hasil uji respon dosen mencapai $81 \%$, sedangkan uji respon mahasiswa 79\%. E-modul yang dirancang tergolong efektif untuk membangkitkan aktivitas dan hasil belajar mahasiswa serta membangun semangat kejujuran dalam menulis karya ilmiah. Hal tersebut terlihat dari hasil pengamatan yang dilakukan observer, dari enam indikator keaktifan berada pada kategori sangat aktif. Hasil belajar yang didapat secara umum berkategori sangat baik.
\end{abstract}

Kata-kata kunci : kualitas, e-modul, CTL, karakter

\section{Abstract}

The success of learning in the classroom is largely determined by lecturers' planning such as the ability of the lecturer in providing the appropriate teaching materials for their classroom. However, teaching materials for scientific writing are still used books or references. There is no specific scientific writing book such as a module integrated by honesty characteristic. Honesty is one of the important characters in scientific writing, so that it is crucial to compile the good quality of that module. This study aims to test the quality of electronic modules ( $e$ modules) based on integrated CTL character education for writing scientific work. The research method used is research and development method which used 4-D model which consist 
of four phases namely: define design, development, and assimilation. in the 3rd stage, namely development. The degree of validity, practicality, and effectiveness of the module are tested in this research. The validity test results show that the validity of this CTL-based e-modules designed is very high with a validity percentage of $82 \%$. E-module is relatively practical both in terms of ease of use and time aspects used. The percentage of the practicality of lecturer response test results reach $81 \%$, while the student response test is $79 \%$. E-modules is quite effective to enhance student activities and learning outcomes and also to build a spirit of honesty in writing scientific work. This can be seen through observation, the six indicators of activeness are in the category very active. The results obtained in general categories are very good.

Keywords : quality, e-module, CTL, character

How to Cite: Winda Noprina, Dina Fitria Handayani. (2021). Kualitas Modul Elektronik Berbasis Contextual Teaching and Learning (CTL) Terintegrasi Pendidikan Karakter untuk Menulis Karya Ilmiah. Ranah: Jurnal Kajian Bahasa. 10(1). 119--131. doi: https://doi.org/10.26499/rnh.v10i1.3347

\section{PENDAHULUAN}

Pada data Scopus, jumlah publikasi ilmiah Indonesia di tingkat ASEAN tahun 2018 mencapai angka 33.953. Menduduki posisi pertama, namun publikasi untuk tahun 2019 Indonesia berada pada posisi kedua di angka 28.374, di bawah Malaysia. Pada rentang 2016-2020 jumlah publikasi melonjak menjadi 161.000. Masih pada peringkat kedua setelah Malaysia. Meski menduduki peringkat dua, jumlah tersebut masih sangat minim jika dibandingkan dengan jumlah dosen dan mahasiswa Indonesia. Jumlah mahasiswa saat ini mencapai 7,3 juta, sedangkan dosen 296.040.

Data tersebut menunjukkan bahwa menulis karya ilmiah masih belum subur membudaya di kalangan insan akademika kampus terutama bagi mahasiswa. Dalam penelitiannya (Rahmiati, 2013) melalui wawancara dan $F G D$ terhadap 56 sampel mahasiswa dari 7 fakultas di UIN Alauddin Makassar menyebutkan berbagai hambatan mahasiswa dalam menulis karya ilmiah. Di antaranya malas, tidak punya mood, kurangnya pemahaman terhadap menulis karya ilmiah, kesulitan dalam menemukan ide, kurang tertarik pada kegiatan menulis, kurang percaya diri, dan kesulitan untuk memulai. Hal tersebut ditemukan (Rahmiati, 2014) dalam penelitiannya.

Penelitian tersebut baru membahas solusi dari dalam diri mahasiswa sendiri. Belum membahas peran dosen dalam upaya meningkatkan kemampuan menulis karya ilmiah mahasiswa. Proses pembelajaran di kelas ditentukan oleh perencanaan yang baik oleh dosen, salah satunya dengan menyediakan sumber belajar. Ketersediaan sumber belajar membantu dosen dalam melaksanakan tugasnya sebagai pengajar, sehingga tujuan, dan sasaran yang diharapkan dapat tercapai. Sebaliknya, mahasiswa harus didorong untuk menemukan sendiri dan mentranformasikan informasi kompleks.

Belajar akan lebih bermakna jika mahasiswa mengalami apa yang dipelajarinya, bukan hanya mengetahuinya. Kurang bervariasinya bahan ajar serta kurang tepatnya penggunaan metode juga dapat menimbulkan hambatan-hambatan dalam menulis. Untuk mengatasi hal itu, diperlukan bahan ajar yang menarik dan mudah diakses seperti modul elektronik (e-modul). Pembelajaran dan pengajaran kontekstual (CTL) yang melibatkan para mahasiswa dalam aktifitas penting yang membantu mereka mengaitkan pelajaran akademis dengan konteks kehidupan nyata menjadi metode yang dinilai dapat. (S. Hidayat, 2012) Pendekatan CTL menjadikan mahasiswa sebagai subjek. Modul berbasis CTL diharapkan mampu mengkonstruksi pelajaran dalam benak mereka sendiri. Mahasiswa tidak sekedar menghafal fakta tapi juga dituntut untuk mengalami dan kemdian tertarik dan menerapkan. 
Penyusunan e-modul untuk penelitian ini menggunakan pendekatan $C T L$. Komponen pendekatan CTL adalah Pemodelan (Modelling), Menemukan (Inquiry), kontruktivisme (Constructivism), Masyarakat Belajar (Learning Community), bertanya (Quuestioning), Refleksi (refleksion), Penilaian Sebenarnya (Autentic Assesment). Pembelajaran dengan pendekatan CTL lebih rinci dan merupakan salah satu metode dosen dalam mengajar. Penerapan model Contextual Teaching and Learning (CTL) dikatakan dapat meningkatkan keterampilan menulis (Eva Maela Sofia, Irfai Fathurohman, 2020).

E-modul yang akan dilihat kualitasnya adalah e-modul yang terintegrasi dengan nilainilai karakter kejujuran. Permasalahan plagiarisme yang selama ini terjadi memperlihatkan bahwa karakter kejujuran ini merupakan titik penting dalam penulisan karya ilmiah. Penelitian yang dilakukan Ercegovac, Zorana dan Richardson, John V. Jr mengatakan perilaku plagiat telah terjadi mulai dari institusi sekolah, perdosenan tinggi sampai dengan masyarakat (Rinusantoro, 2014). Kejahatan intelektual berupa plagiarisme sepertinya sudah menjadi fenomena umum dalam dunia pendidikan maupun masyarakat kita (Lako, 2012).

Pada situasi pembelajaran di kelas, bentuk ketidakjujuran akademis seperti copy paste (menyalin dan menempel) telah lazim dilakukan oleh para mahasiswa. Maraknya upaya pembuatan aplikasi yang dapat mendeteksi plagiat juga merupakan tanda bahwa ketidakjujuran sudah sampai pada tahap yang memprihatinkan. Sementara itu, dalam standar nasional pendidikan tinggi disebutkan bahwa salah satu capaian afektif yang harus dimiliki mahasiswa adalah mampu menginternalisasi nilai, norma dan etika akademik, (SN Dikti). Berdasarkan realita tersebut, penting untuk melihat tingkat kualitas e-modul berbasis pendekatan $C T L$ terintegrasi pendidikan karakter khususnya karakter jujur untuk pembelajaran menulis karya ilmiah (Eva Maela Sofia, Irfai Fathurohman, 2020).

Penelitian ini bertujuan untuk melihat kualitas dari e-modul berbasis $C T L$ terintegrasi pendidikan karakter khususnya karakter jujur untuk menulis karya ilmiah. Kualitas tersebut dilihat dari sisi validitas, praktikalitas, dan efektivitas penggunaan e-modul.

\section{LANDASAN TEORI}

Modul adalah salah satu bahan ajar yang efektif dalam mencapai tujuan pembelajaran. Sebagai paket belajar mandiri, modul dirancang sistematis membantu peserta didik mencapai tujuan belajar. Saat ini, modul telah disajikan pula dalam bentuk elektronik. (Zaharah \& Susilowati, 2020) menyebutkan modul elektronik merupakan media yang dapat menyampaikan gambar, video dan animasi untuk meningkatkan pemahaman peserta didik.

Modul elektronik atau e-modul merupakan tampilan informasi dengan bentuk penyajian bahan belajar mandiri yang disusun secara sistematis ke dalam unit pembelajaran terkecil untuk mencapai tujuan pembelajaran tertentu yang disajikan dalam format buku secara elektronik dengan menggunakan hard disk atau flash disk dan dapat dibaca dengan menggunakan komputer atau bahkan smartphone. Modul elektronik mamu melibatkan semakin banyak indera dalam belajar. (Hafsah et al., 2016) mengatakan pengalaman belajar dan media pembelajaran yang semakin banyak anggota tubuh yang terlibat dalam proses pembelajaran, maka tingkat kompetensi yang didapatkan oleh peserta didik juga semakin banyak, antara lain kognitif, keterampilan, dan sikap.

Penerapan model Contectual Teaching and Learning (CTL) dalam e-modul diharapkan dapat membuat mahasiswa lebih mudah untuk memahami pembelajaran yang dipelajarinya secara alami tanpa harus menghafal. CTL dapat mengaitkan materi dengan kehidupan seharihari sehingga siswa mudah untuk memahaminya dan siswa tidak jenuh untuk belajar. Mulyasa (Eva Maela Sofia, Irfai Fathurohman, 2020) menyatakan bahwa model CTL sebagai acuan pembelajaran, dosen dapat menyampaikan materi pembelajaran dengan gambaran kondisi nyata yang ada di lingkungan sekitar. CTL merupakan pembelajaran yang mengedepankan 
terciptanya lingkungan belajar yang mengaitkan kehidupan sehari-hari. Dalam pendekatan model CTL, dosen memberikan kondisi pembelajaran yang nyaman agar mahasiswa antusias untuk dapat memahami dan dapat meningkatkan hasil belajar (Eva Maela Sofia, Irfai Fathurohman, 2020). Model ini sangat cocok digunakan untuk pembelajaran menulis karya ilmiah khususnya makalah.

Integrasi pendidikan karakter dalam e-modul dapat juga membantu menguatkan karakter kejujuran pada mahasiswa dalam menulis karya ilmiah. (Susanti, 2013) menyebutkan pendidikan karakter merupakan pendidikan nilai, pendidikan budi pekerti, pendidikan moral, pendidikan watak, yang bertujuan mengembangkan kemampuan peserta didik untuk memberikan keputusan baik-buruk, memelihara apa yang baik, mewujudkan dan menebar kebaikan itu dalam kehidupan sehari-hari dengan sepenuh hati. Dalam e-modul ini pendidikan karakter ditekankan pada karakter kedua yakni jujur. Jujur merupakan prilaku yang didasarkan pada upaya menjadikan dirinya sebagai orang yang selalu dapat dipercaya dalam perkataan, tindakan, dan pekerjaan. Sehingga karakter ini dapat diterapkan mahasiswa dalam menyusun karya-karya ilmiahnya.

\section{METODE PENELITIAN}

Penelitian ini menggunakan metode 4D. Selain tahapan penelitian yang dilakukan pada model ini lebih singkat dari model pengembangan lainnya, model ini juga mudah dan cocok untuk diterapkan pada pengembangan bahan ajar, model ini juga telah banyak dipakai oleh peneliti sebelumnya. Penelitian ini merupakan bagian dari penelitian pengembangan metode 4D pada tahap pengembangan atau develop. Metode yang digunakan dalam penelitian ini adalah metode analisis deskriptif kualitatif, karena penelitian ini bertujuan untuk mendeskripsikan kualitas dari e-modul berbasis CTL terintegrasi pendidikan karakter untuk menulis karya ilmiah mahasiswa.

Sebelum e-modul dibagikan kepada mahasiswa, e-modul terlebih dahulu divalidasi oleh para ahli. Jika e-modul layak untuk dijadikan bahan ajar, maka tahapan dilanjutkan pada tahap uji praktikalitas dan efektivitas. Adapun subjek uji coba dari penelitian ini adalah 40 mahasiswa angkatan 2019 Prodi Pendidikan Guru Sekolah Dasar STKIP Adzkia dan 2 dosen pengampu mata kuliah Menulis Karya Ilmiah. Mahasiswa dan dosen diberikan e-modul berbasis CTL terintegrasi pendidikan karakter untuk menulis karya ilmiah mahasiswa.

Adapun metode pengumpulan data, instrumen pengumpulan data dan tujuan tiap tahap develop disajikan pada Tabel 1.

Tabel 1

Kegiatan Pengumpulan Data

\begin{tabular}{|c|c|c|}
\hline & Instrumen & Tujuan \\
\hline Uji Validitas & Angket & $\begin{array}{l}\text { Mengetahui tingkat validasi modul dari segi } \\
\text { kelayakan isi, pengajian, kebahasaan dan } \\
\text { kegrafikaan. }\end{array}$ \\
\hline Uji Praktikalitas & Angket & $\begin{array}{l}\text { Melihat kondisi apakah modul yang } \\
\text { diujicobakan dapat membantu dosen dan } \\
\text { mahasiswan sehingga pembelajaran yang } \\
\text { dilakukan bermakna, menarik, dan } \\
\text { menyenangkan dan berguna bagi kehidupan } \\
\text { mahasiswa. }\end{array}$ \\
\hline Uji Efektivitas & $\begin{array}{l}\text { Lembar observasi dan data skor penulisan } \\
\text { makalah }\end{array}$ & $\begin{array}{l}\text { Melihat kelayakan modul dan ketercapaian } \\
\text { tujuan daro modul yang dikembnagkan } \\
\text { dalam proses pembelajaran. }\end{array}$ \\
\hline
\end{tabular}

Hasil ketiga pengujian tersebut akan memperlihatkan kualitas dari modul elektronik berbasis contectual teaching and learning (CTL) terintegrasi pendidikan Karakter. 


\section{PEMBAHASAN}

E-modul berbasis $C T L$ terintegrasi pendidikan karakter untuk menulis karya ilmiah mahasiswa yang sudah dirancang dan dikembangkan dengan menggunakan aplikasi flipbook maker adalah sebagai berikut.

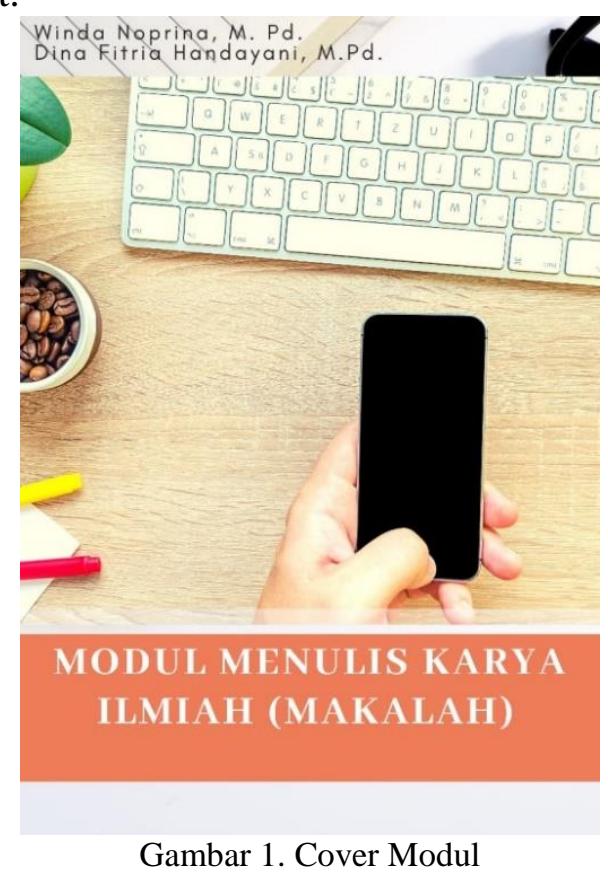

Gambar di atas merupakan cover modul yang berisi judul modul, nama penulis, dan gambar ilustrasi.

Sedangkan gambar 3 merupakan bagian pendahuluan. Bagian ini memuat penjelasan tentang learning outcome, prasyarat dan petunjuk penggunaan modul. Pada bagian ini sudah mulai disajikan video. Pada bawah modul juga dapat dilihat tombol-tombol yang dapat diaplikasikan oleh mahasiswa dalam menggunakan modul.

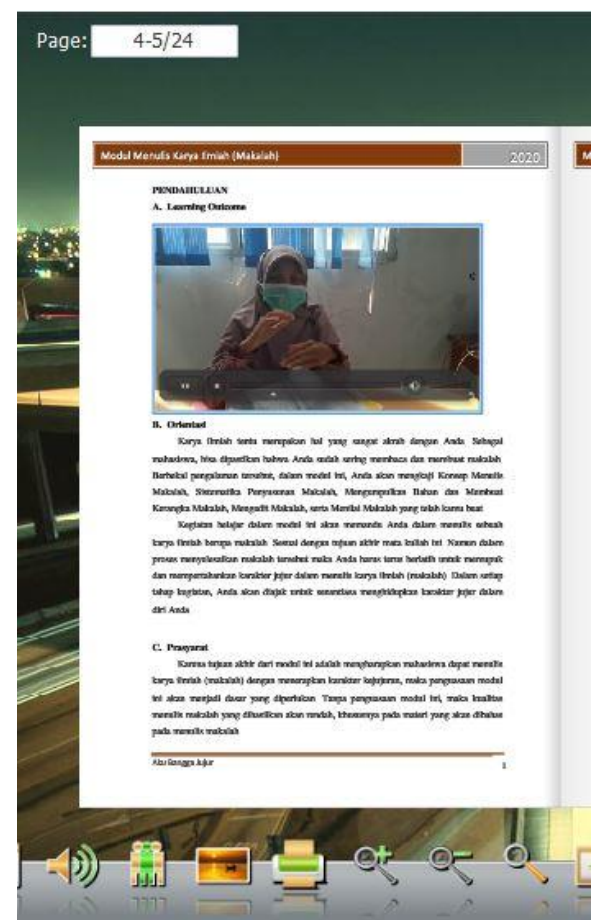

Gambar 2. Bagian Pendahuluan E-Modul 
Gambar 2 merupakan bagian Kegiatan Belajar. Bagian ini memuat tentang kegiatan pembelajaran mulai dari materi, juga aktivitas-aktivitas seperti menjawab pertanyaan melalui link yang dapat tersambung langsung ke kolom pengerjaan soal atau jawaban.

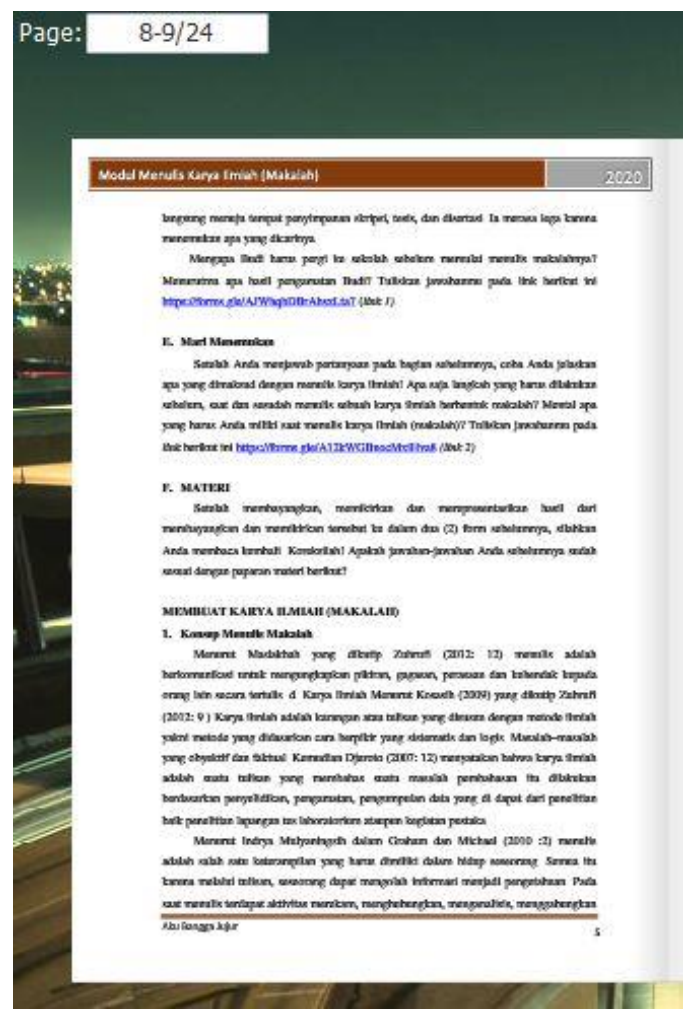

Gambar 3. Bagian Aktivitas Mahasiswa

Refleksi-refleksi membangkitkan semangat kejujuran

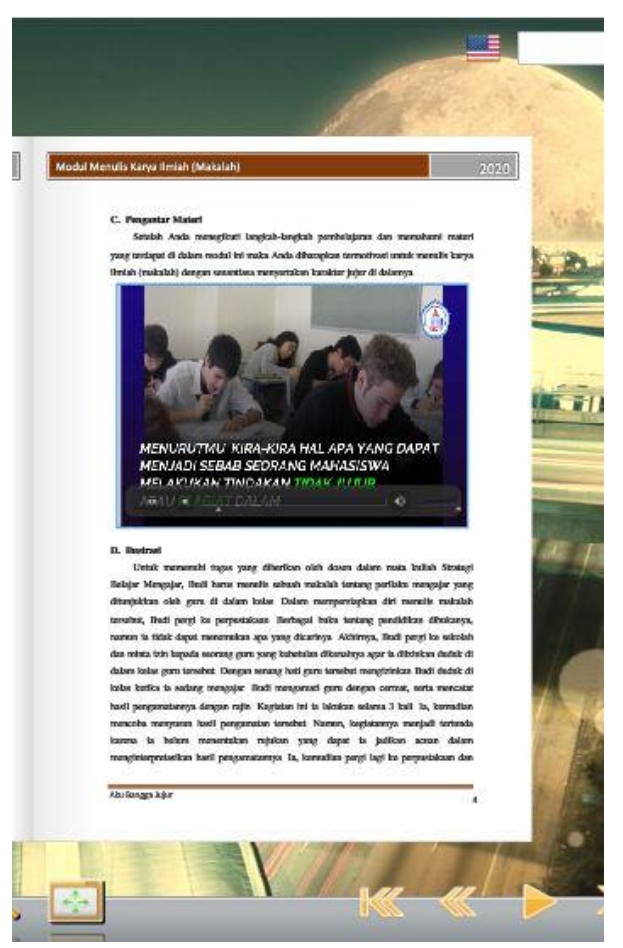

Gambar 4. Refleksi 
Pada bagian akhir modul, terdapat penilaian. Disediakan rubrik penilaian makalah. Rubrik ini membuat mahasiswa dapat menilai sendiri hasil dari karya menulis makalahnya.

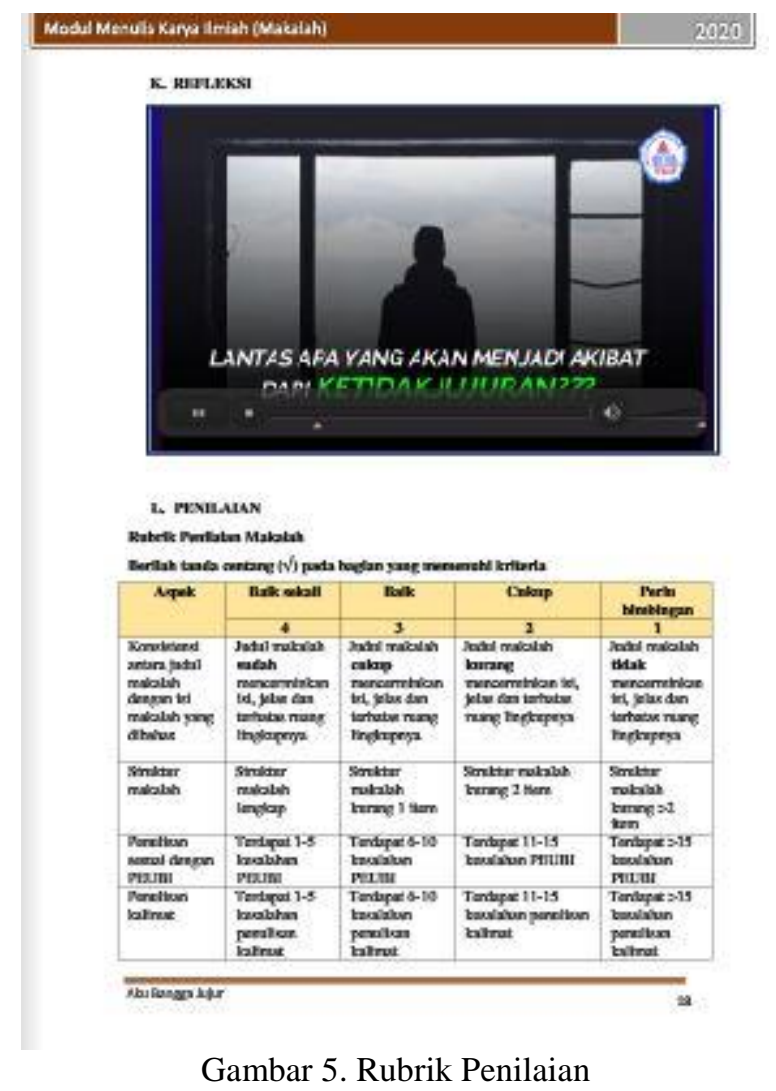

\section{Uji Validitas $E$-Modul}

Setelah e-modul selesai disusun maka dilakukan validasi terhadap modul yang sudah disusun. Validasi e-modul dibantu oleh beberapa pakar : Zaturrahmi, M.Pd., Lisa Yuniarti, M.Pd. (Ahli Pembelajaran dan Kebahasaan), dan Romi Kurniawan, S.Pd. (Praktisi Design Komunikasi Visual). Ketiga Validator merupakan pakar yang menilai aspek kelayakan isi, kebahasaan e-modul dan kelayakan kegrafikaan. Jawaban yang diberikan validator berdasarkan skala Likert. Skor dijumlahkan per-aspek dan per-validator. Perhitungan data nilai akhir validasi dianalisis dalam skala (0-100) dilakukan dengan rumus yang diperkenalkan Purwanto (Rohman, 2017). Skor maksimal pada validasi aspek kelayakan isi adalah 160. Pada aspek kelayakan kebahasaan adalah 64. Kelayakan kegrafikaan yakni 108. Adapun rumus perolehan nilai validitas adalah sebagai berikut.

$$
\text { Nilai Validitas }=\frac{\text { Perolehan Skor }}{\text { Skor Maksimal }} \times 100 \%
$$

Tabel 2

Kategori Validitas E-Modul

\begin{tabular}{ll}
\multicolumn{2}{c}{ Kategori Validitas E-Modul } \\
\hline \multicolumn{1}{c}{ Tingkat Pencapaian (\%) } & \multicolumn{1}{c}{ Kategori } \\
\hline $81-100$ & Sangat Valid \\
\hline $61-80$ & Valid \\
\hline $41-60$ & Cukup Valid \\
\hline
\end{tabular}


Kualitas Modul Elektronik Berbasis.....

\begin{tabular}{lc}
\hline $21-40$ & Kurang Valid \\
\hline $0-20$ & Tidak Valid \\
\hline & (dimodifikasi dari Riduwan, 2012:89)
\end{tabular}

Nilai validitas secara keseluruhan adalah sebagai berikut.

Tabel 3

Hasil Validasi E-Modul

\begin{tabular}{lcccl}
\hline \multicolumn{1}{c}{ Aspek Validasi } & Skor & Skor Total & $\begin{array}{c}\text { Persentase } \\
\text { Validitas }\end{array}$ & Kategori \\
\hline Kelayakan Isi & 134 & 160 & $84 \%$ & Sangat Valid \\
\hline Kelayakan Kebahasaan & 57 & 64 & $89 \%$ & Sangat Valid \\
\hline Kelayakan Kegrafikaan & 76 & 108 & $70 \%$ & Valid \\
\hline Kelayakan Penyajian & 137 & 160 & $86 \%$ & Sangat Valid \\
\hline Total Validitas & $\mathbf{4 0 4}$ & $\mathbf{4 9 2}$ & $\mathbf{8 2 \%}$ & Sangat Valid \\
\hline
\end{tabular}

$$
\text { Nilai Validitas }=\frac{404}{492} \times 100 \%=82 \%
$$

Validitas e-modul berada dalam kategori sangat valid dengan presentase validitas $82 \%$. Jika dirinci, maka validitas e-modul berdasarkan aspek kelayakan isi, kelayakan kebahasaan, kelayakan kegrafikaan, dan kelayakan penyajian adalah seperti terdapat dalam grafik di bawah ini.

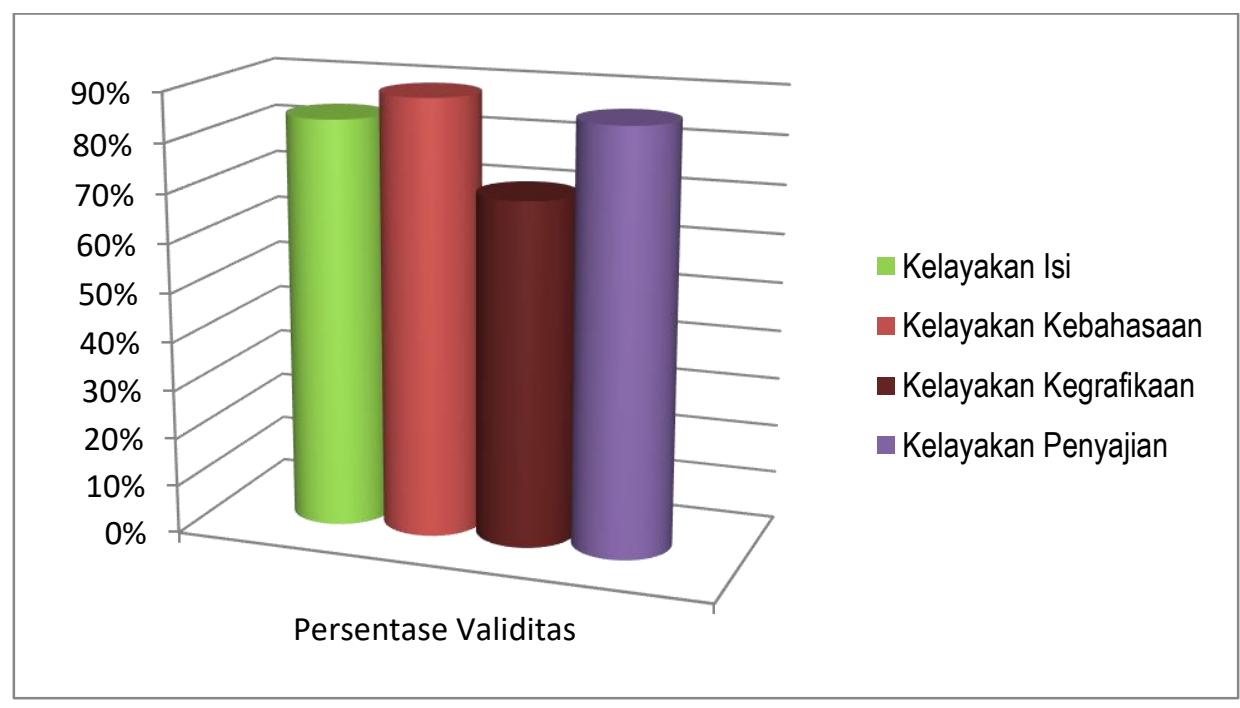

Gambar 6. Tingkat Validitas E-modul berdasarkan Empat Aspek.

Dengan tingkat validitas tersebut, e-modul ini masih memiliki beberapa perbaikan sebelum diujicobakan. Perbaikan dilakukan berdasarkan saran-saran dari validator sebagai berikut.

Tabel 4

Saran Validator

\begin{tabular}{l}
\hline Saran \\
\hline Perbaikan PUEBI \\
Beberapa kesalahan penulisan, tanda baca dan ejaan diperiksa kembali dengan teliti. \\
\hline Integrasi CTL \\
Integrasi pendekatan CTL harus lebih dikuatkan lagi dalam proses kegiatan belajar pada modul. \\
\hline Perbaikan latar video, penggunaan gambar, ukuran font \\
\hline
\end{tabular}




\section{Uji Praktikalitas E-Modul}

Setelah dilakukan perbaikan terhadap e-modul maka dilakukan uji praktikalitas terhadap penggunaan e-modul. (Noprina, 2019) Uji praktikalitas ini dilakukan untuk melihat kepraktisan dari e-modul. Modul digunakan pada kelas menulis karya ilmiah (makalah). Setelah itu diberikan angket pada dua orang dosen dan 40 mahasiswa untuk melihat respon mereka terhadap kepraktisan modul. Adapun hasil uji praktikalitas e-modul dari respon dosen adalah sebagai berikut.

Tabel 5

Tabel Perolehan Skor Praktikalitas (Uji Respon terhadap Dosen)

\begin{tabular}{lcccc}
\hline Pernyataan/Dosen & $\begin{array}{c}\text { Kemudahan dalam } \\
\text { Menggunakan }\end{array}$ & Waktu yang Digunakan & Skor Maks & Skor Maks \\
\hline Dosen 1 & 48 & 6 & 68 & 68 \\
\hline Dosen 2 & 50 & 6 & 68 & 68 \\
\hline & & Total Skor & & 136 \\
\hline
\end{tabular}

Skor tersebut kemudian diolah berdasarkan rumus total skor perolehan dibagi skor maksimum dan dikalikan $100 \%$. Setelah data tersebut diolah maka hasil data praktikalitas dikonversikan dalam kategori seperti dalam tabel 6 .

Tabel 6

Kategori Praktikalitas E-Modul

\begin{tabular}{ll}
\hline \multicolumn{1}{c}{ Interval (\%) } & \multicolumn{1}{c}{ Kategori } \\
\hline $81-100$ & Sangat Praktis \\
\hline $61-80$ & Praktis \\
\hline $41-60$ & Kurang Praktis \\
\hline $21-40$ & Tidak Praktis \\
\hline $0-20$ & Sangat tidak praktis \\
\hline & (dimodifikasi dari (Riduwan, 2010)
\end{tabular}

Nilai praktikalitas secara keseluruhan adalah sebagai berikut.

Nilai Praktikalitas $=\frac{110}{136} \times 100 \%=81 \%$ (sangat praktis)

Nilai praktikalitas aspek kemudahan dalam penggunaan

$$
\text { Nilai Praktikalitas }=\frac{98}{120} \times 100 \%=82 \%
$$

Nilai praktikalitas aspek kemudahan waktu yang digunakan

$$
\text { Nilai Praktikalitas }=\frac{12}{16} x 100 \%=75 \%
$$

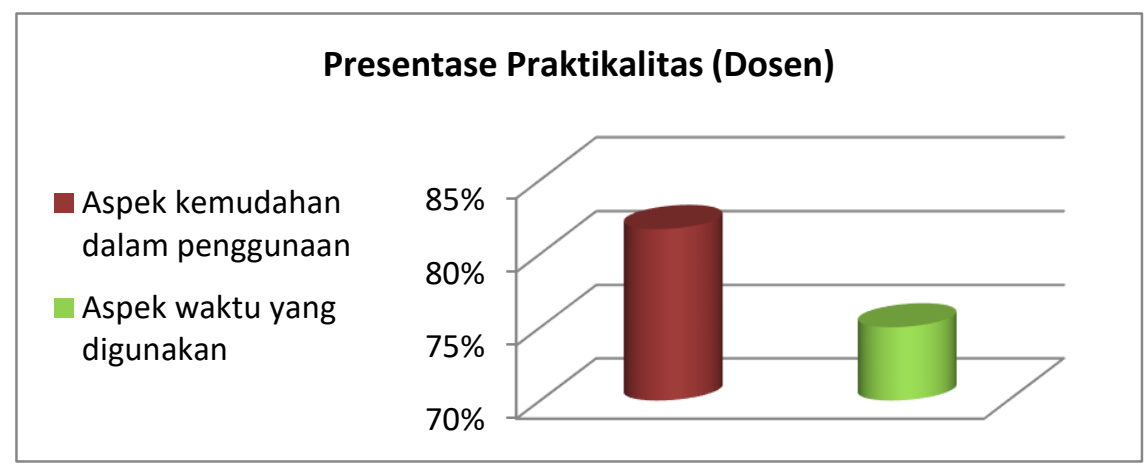


Gambar 7. Tingkat Praktikalitas E-modul (uji respon dosen)

Sedangkan untuk uji praktikalitas terhadap penggunaan e-modul oleh mahasiswa dilakukan pada 40 mahasiswa. Hasil uji praktikalitas e-modul dari respon mahasiswa adalah sebagai berikut.

$$
\text { Nilai Praktikalitas }=\frac{2141}{2170} \times 100 \%=79 \%
$$

Adapun nilai praktikalitas per-indikator adalah sebagai berikut.

Tabel 7. Tabel Perolehan Skor Praktikalitas (Uji Respon terhadap Mahasiswa)

\begin{tabular}{llcccl}
\hline No & Indikator Praktikalitas & Skor & $\begin{array}{c}\text { Skor } \\
\text { Maks. }\end{array}$ & $\begin{array}{c}\text { Persentase } \\
\text { Praktikalitas }\end{array}$ & Kategori \\
\hline 1 & Kemudahan dalam Penggunaan & 1889 & 2400 & $79 \%$ & Praktis \\
\hline 2 & Waktu yang Digunakan & 252 & 320 & $79 \%$ & Praktis \\
\hline
\end{tabular}

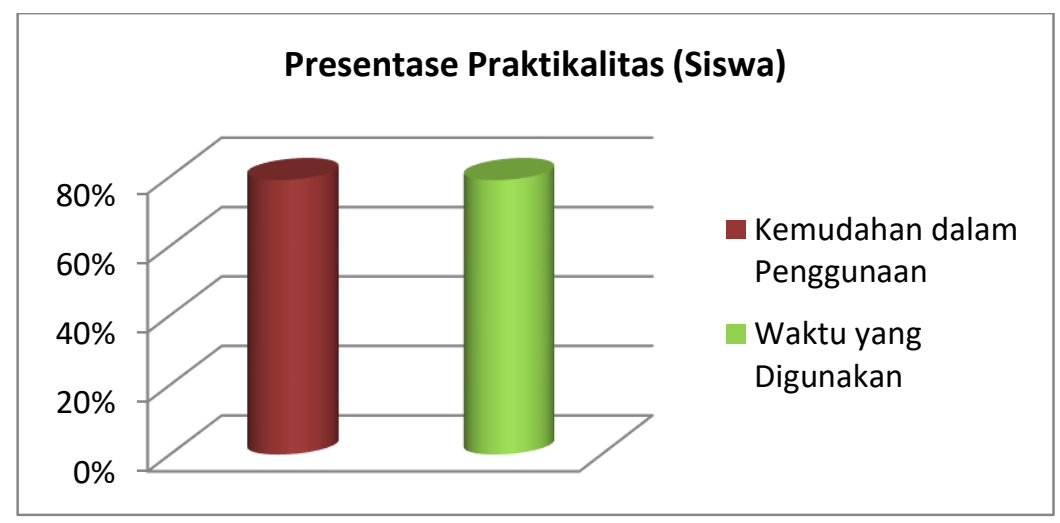

Gambar 8. Tingkat Praktikalitas E-modul (uji respon mahasiswa)

Dari data uji praktikalitas di atas diperoleh kesimpulan bahwa e-modul berbasis pendekatan Contextual teaching and Learning (CTL) terintegrasi pendidikan karakter untuk menulis karya ilmiah (makalah) berada pada kategori sangat praktis dengan perolehan persentase $81 \%$. Sedangkan menurut responden dosen dan praktis dengan perolehan persentase $79 \%$ menurut responden mahasiswa.

\section{Uji Efektivitas $E$-Modul}

Uji Efektifitas modul dapat diketahui melalui dua bentuk yaitu aktivitas mahasiswa dan tes unjuk kerja menulis makalah. Modul yang telah direvisi digunakan dalam proses pembelajaran. Modul yang disusun bertujuan agar mahasiswa dapat belajar mandiri dengan atau tanpa arahan dari dosen. Modul pembelajaran ini diberikan pada mahasiswa STKIP Adzkia sebagai subjek uji coba. Mahasiswa diberikan arahan dalam menggunakan modul dan diberikan kesempatan selama satu minggu untuk mempelajari modul pembelajaran menulis karya ilmiah (makalah) berbasis Contexstual Teaching and Learning (CTL) sembari juga menyelesaikan tugas menulis makalah. Setelah satu minggu, mahasiswa dikumpulkan kembali untuk mengumpulkan tugas menulis makalah. Aktivitas mahasiswa dinilai melalui kegiatan-kegiatan yang dilakukan mahasiswa serta hasil penilaian makalah. Aktivitas mahasiswa yang diamati mencakup enam aspek. Saat pembelajaran berlangsung, melibatkan 2 orang observer.

Tabel 8

Perolehan Skor Pengamatan terhadap Aktivitas Mahasiswa dalam Pembelajaran saat Menggunakan E-modul 


\begin{tabular}{llll}
\hline \multicolumn{1}{c}{ Aspek yang Diamati } & $\begin{array}{c}\text { Rata-rata Skor } \\
\text { Penilaian } \\
\text { Observer }\end{array}$ & $\begin{array}{c}\text { Persentase } \\
(\%)\end{array}$ & Kategori \\
\hline $\begin{array}{l}\text { perhatian mahasiswa terhadap pembelajaran } 32 \\
\text { dengan menggunakan modul. }\end{array}$ & $80 \%$ & Aktif \\
\hline $\begin{array}{l}\text { Mahasiswa menuliskan peristiwa yang } 38 \\
\text { dialaminya berdasarkan ilustrasi yang ada dalam } \\
\text { modul. }\end{array}$ & $95 \%$ & Sangat Aktif \\
\hline $\begin{array}{l}\text { Mahasiswa mengerjakan semua aktivitas dalam } 36,5 \\
\text { modul. }\end{array}$ & $91 \%$ & Sangat Aktif \\
\hline $\begin{array}{l}\text { Mahasiswa mengerjakan refleksi jurnal } 27 \\
\text { mahasiswa yang terdapat pada akhir kegiatan } \\
\text { pembelajaran modul. }\end{array}$ & $68 \%$ & Sangat Aktif \\
\hline $\begin{array}{l}\text { Mahasiswa mencocokkan jawaban dengan } 38 \\
\text { intisari jawaban yang ada untuk mengetahui } \\
\text { tingkat pemahamannya serta menilai sendiri } \\
\text { pekerjaannya sesuai dengan rubrik penilaian yang } \\
\text { disediakan dalam modul. }\end{array}$ & $95 \%$ & \\
\hline $\begin{array}{l}\text { Makalah yang disusun mahasiswa tidak } 33 \\
\text { merupakan copy paste (dilihat dari pengoreksian } \\
\text { makalah dan uji turnitin kurang dari 30\%) }\end{array}$ & & Sangat Aktif \\
\hline
\end{tabular}

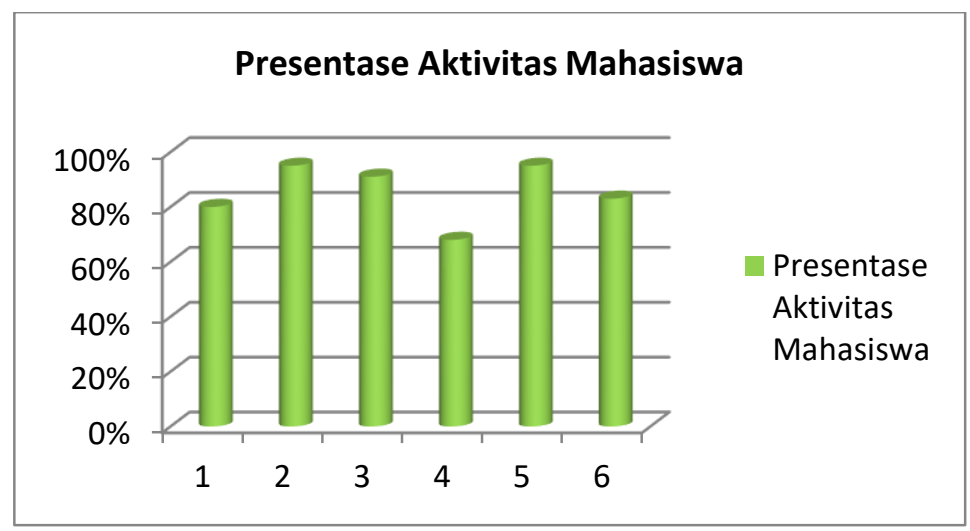

Gambar 9. Tingkat Aktivitas Mahasiswa saat Menggunakan E-modul

Selain melalui pengamatan, efektivitas modul juga dinilai melalui tes unjuk kerja menulis makalah yang dilakukan mahasiswa. Setelah mahasiswa mempelajari modul pembelajaran dan mengerjakan tugas serta latihan yang terdapat dalam modul, penilaian terhadap makalah yang ditulis adalah untuk mengukur sejauh mana kemampuan mahasiswa dalam menulis karya ilmiah makalah. Barikut hasil tes unjuk kerja diberikan kepada mahasiswa STKIP Adzkia.

Tabel 9

Perolehan Skor Menulis Makalah

\begin{tabular}{ccccc}
\hline Skor & Angka & Huruf & $\begin{array}{l}\text { Jumlah } \\
\text { Mahasiswa }\end{array}$ & $\begin{array}{l}\text { Persentase Nilai } \\
\text { Mahasiswa }\end{array}$ \\
\hline $76-100$ & 4 & A & 27 & $67,5 \%$ \\
\hline $51-75$ & 3 & B & 13 & $32,5 \%$ \\
\hline $26-50$ & 2 & C & 0 & 0 \\
\hline $1-25$ & 1 & D & 0 & 0 \\
\hline 0 & 0 & E & 0 & 0 \\
\hline & Total & & 40 & $100 \%$ \\
\hline
\end{tabular}


Dari data yang telah diuraikan di atas terlihat bahwa tingkat keaktifan mahasiswa saat menggunakan e-modul adalah $85 \%$, bearda pada kategori sangat aktif. Dari skor penilaian menulis makalah $67,5 \%$ memperoleh nilai A, sedangkan 32,5\% memperoleh nilai B. Maka dapat disimpulkan bahwa e-modul berbasis pendekatan Contextual teaching and Learning (CTL) terintegrasi pendidikan karakter untuk menulis karya ilmiah (makalah) ini sangat efektif untuk membangkitkan aktivitas dan hasil belajar mahasiswa serta membangun semangat kejujuran dalam menulis karya ilmiah.

\section{PENUTUP}

Berdasarkan hasil penelitian yang telah dipaparkan sebelumnya, maka dapat ditarik beberapa kesimpulan. Pertama, $e$-modul berbasis CTL yang dirancang tergolong sangat valid. Dengan demikian, modul sudah dapat digunakan oleh dosen dan mahasiswa. Validitas modul ini tergambar dari beberapa aspek yakni aspek kelayakan isi. Modul yang dirancang sudah merujuk pada CPL, CPMK yang ada dalam KKNI dan pembelajaran yang disajikan telah mencantumkan tahap CTL. Dari Aspek kebahasaan modul telah sesuai PUEBI, mudah dipahami dan membangkitkan semangat dalam belajar. Dari aspek penyajian, modul telah dibuat sesuai dengan kurikulum, mudah dipahami mahasiswa, menumbuhkan kesadaran dan semangat, serta sesuai dengan kemajuan zaman. Dari aspek kegrafikaan, modul mudah dibaca, warna menarik, dan membangkitkan aktivitas mahasiswa.

Modul yang dirancang tergolong praktis baik dari aspek kemudahan dalam penggunaan maupun aspek waktu yang digunakan. Modul yang diranacang tergolong efektif untuk membangkitkan aktivitas dan hasil belajar mahasiswa serta membangun semangat kejujuran dalam menulis karya ilmiah. Hal tersebut terlihat dari hasil pengamatan yang dilakukan observer, dari enam indikator keaktifan berada pada kategori sangat aktif. Hasil belajar yang didapat secara umum berkategori sangat baik.

\section{DAFTAR PUSTAKA}

Eva Maela Sofia, Irfai Fathurohman, I. P. (2020). Penerapan Model Contextual Teaching and Learning terhadap Peningkatan keterampilan Menulis Pendapat Pribadi. Kredo: Jurnal Ilmiah Bahasa dan Sastra, 3, 249-262. https://doi.org/10.24176/kredo.v3i2.4783

Hafsah, N. R. J., Rohendi, D., \& Purnawan. (2016). E-Modul Sebagai Media dalam Penigkatan Kualitas Belajar. Jurnal Teknik Mesin, 03(01), 106-112. https://doi.org/10.17509/jmee.v3i1.3200

Lako, A. (2012). Plagiarisme Akademik. Harian Jawa Pos Radar Semarang, 1-7. https://storage.kopertis6.or.id/

Noprina, W. (2019). Pengembangan Modul Menulis Cerpen berbasis Project Based Learning (PJBL) untuk Siswa MA Ar-Risalah. Bahastra, 4 No.1(1), 162-169.

Rahmiati. (2013). Problematika Mahasiswa dalam Menulis Karya Ilmiah. Jurnal Adabiyah, 13(2), 160-175. http://103.55.216.56/index.php/adabiyah/article/view/-363

Rahmiati. (2014). Analisis Kendala Internal Mahasiswa dalam Menulis Karya Ilmiah. AlDaulah, 3(2), 254-269. https://doi.org/https://doi.org/10.24252/ad.v3i2.1513

Riduwan. (2010). Belajar Mudah Penelitian untuk Guru-Karyawan dan Peneliti Pemula. In Alfabeta. Alfabeta.

Rinusantoro, S. (2014). Aplikasi Deteksi Kemiripan Dokumen Teks.

Rohman, W. A. (2017). Motivasi Belajar Siswa melalui Pembelajaran KOntekstual Berintegrasi Nilai-nilai Islam. Jurnal Pi, Pend. Mat. STKIPH, 1(01), 27-31. https://core.ac.uk/

S. Hidayat, M. (2012). Pendekatan Kontekstual dalam Pembelajaran. Insania, 17(2), 231-247. https://doi.org/https://doi.org/10.24090/insania.v17i2.1500 
Susanti, R. (2013). Penerapan Pendidikan Karakter di Kalangan Mahasiswa. Al-Ta Lim Journal, 20(3), 480-487. https://doi.org/10.15548/jt.v20i3.46

Zaharah, Z., \& Susilowati, A. (2020). Meningkatkan Motivasi Belajar Peserta Didik dengan Menggunakan Media Modul Elektronik di Era Revolusi Industri 4.0. Biodik, 6(2), 145158. https://doi.org/10.22437/bio.v6i2.8950 